\title{
The Construction of the Professional Teaching Model for Cultivating College Accounting Capability Based on the Internationalization of Accounting
}

\author{
Sun Limei \\ Xi'an Peihua University, Xi'an, Shaanxi, China, 710125
}

Keywords: accounting internationalization; college accounting ability training; professional teaching model

\begin{abstract}
With the rapid development of China's modern economy, accounting has gradually developed toward the internationalization direction, and China's accounting regulations and accounting practices have been pushed to a higher level and are in line with international standards. Faced with this situation, companies must cultivate more qualified international accounting personnel and adapt to the internationalization of accounting education. The accounting professional teaching in colleges and universities is the main place for cultivating accounting talents, and it is the key goal to complete the integration of accounting education with internationalization. However, at this stage, the traditional teaching pattern of the accounting professional teaching model still follows the traditional teaching model, paying too much attention to theoretical teaching and knowledge transfer, thus ignoring the cultivation of practice and capacity. As a result, students who graduate from accounting major lack the coping ability in the face of emergencies and do not meet the development needs of internationalization. In this regard, colleges and universities will change the teaching model of the accounting profession and create a new teaching mode to cultivate accounting skills.
\end{abstract}

\section{Introduction}

Based on the accounting international background, although each university has implemented a different degree of teaching model construction, it still does not meet the comprehensive and scientific teaching standard for the current accounting teaching model, and still have some distance from the talent training objectives put forward by the accounting profession. Nowadays, the construction of college accounting professional teaching mode is implemented on the basis of a sound teaching program, and innovation and reform of the teaching model are carried out so as to improve students' comprehensive quality and practical capability. The construction of accounting teaching mode can not only deepen students' understanding of theoretical knowledge, but also enable them to use flexibly and improve their own quality.

\section{The Necessity of Training Students' Ability in Accounting Internationalization}

Accounting internationalization refers to the fact that due to the influence of international economic development, each country is required to apply international accounting conventions in various reports such as accounting policies, accounting education, accounting matters, and accounting management systems. Accounting transaction work has been moving toward standardization, unification, coordination, and standardization. In addition, you can use internationally accepted accounting principles and accounting methods to handle accounting work. [3]

\subsection{The impact of accounting internationalization on accounting teaching}

In the internationalization of accounting, the accounting environment is very important, especially the changes in the economic environment have a great impact on the accounting work. In this regard, the state has put forward new requirements for accounting teaching. First, the effect on the accounting talent structure. In order to meet the needs of the society, the accounting profession 
in colleges and universities continuously trains and conveys accounting talents. However, due to the internationalization of accounting, the accounting talent structure in China has changed. The demand for accounting talents in society has become diversified, which to a certain extent determines the level of higher accounting teaching in our country. Second, the impact on the skill level of accountants. The main reason for the change of China's accounting external environment is the internationalization of accounting. In order to increase the level of accounting supervision and the quality of accounting information, more and more professional accounting personnel with high quality and comprehensive ability must be trained. In the process of international accounting development, our country's accounting teaching model is relatively backward and cannot meet the development trend of economic globalization. Third, the influence on accounting education goals. The goal of accounting education is the premise basis of the accounting education model, which plays a decisive role in the development of accounting education. Nowadays, China has not established the main goal of accounting education, and there is not a general understanding of education and professional circles. The internationalization of this accounting requires our country to regard the market demand as the main goal of accounting education, and take training skills as the core. Besides, we must comply with the requirements of international accounting development, combine accounting education content, and define specific teaching targets. Fourth, the impact on accounting education thinking. In the traditional concept of accounting education, the still-used academic teaching, although it has added practical courses in various universities, still focuses on learning theory and neglects the cultivation of students' professional skills. However, in the international teaching of accounting, it is necessary to establish a teaching model that integrates with international practice, using students as teaching subjects and changing the traditional teaching philosophy.

\subsection{The internationalization of accounting requires accounting professional teaching model to emphasize the cultivation of students' abilities.}

The accounting education reform committee to which the American Accounting Society belongs announced the main goal of accounting education in an announcement in September 1990. Guiding students with independent learning literacy is the core goal of accounting education. The education received on the university campus is the basis of student learning so that students can independently learn new cultural knowledge after graduation. In this regard, the core condition for cultivating accounting personnel's survival and success is the independent learning ability. At this stage, China's accounting education does not regard the cultivation of student's capability as an educational goal. Students' understanding of accounting only comes from books, and they do not have the ability to work independently. Due to the influence of the traditional accounting education model, students do not have a sense of innovation and cannot meet the requirements for the development of accounting internationalization. Therefore, whether it is a college-level accounting education or an undergraduate accounting education, we must attach great importance to the development of students' professional skills and lay a foundation for students' future career advancement. In this regard, it is very important to create a professional teaching model aimed at cultivating competence.

\section{The Principle of Building Professional Teaching Mode of Competence Training}

\subsection{Accounting professional structure}

The earliest occupational structure of accounting personnel occurred in the 1960s. The American Institute of Certified Public Accountants began to discuss and analyze the capabilities of accounting personnel, and in 1999 it introduced the "Core Competency Framework for Entering Accounting Professionals ". During the year 2003, the International Federation of Accountants launched the "Become a Competent Certified Public Accountant" and improved the capabilities of accountants in each country. At this stage, both domestic and international are discussing and analyzing the accounting professional ability structure, and propose to create a professional structure of 
accounting personnel with strong comprehensive ability. Business competence, professional quality and professional knowledge are the main components of comprehensive ability. In the accounting international context, the professional teaching model for the cultivation of university accounting ability should be based on the professional standards of the accounting profession, and then based on the detailed accounting education objectives, a reasonable occupational structure system for accountants should be established. The occupational structure is mainly divided into three categories: the first category, basic capabilities. It is a professional qualification that accounting students must possess, which mainly include: knowledge acquisition and information ability, practical operation ability, writing ability, interpersonal communication ability, language expression ability, self-adjustment ability and honesty and trustworthiness. The second category, professional ability. The professional competence of general accountants mainly includes: professional judgment ability, professional competence, information processing ability, problem solving ability, professional ethics, team spirit, and risk prevention awareness. The third category, development ability, is a basic requirement for senior accountants. It mainly includes: critical thinking ability, ability to grasp laws and regulations, management decision-making ability, ability to observe professional ethics to curb bad temptation, innovation ability, and environmental adaptability. [8].

\subsection{The construction principle of competency training teaching mode}

In accordance with the professional structure of college students accounting to create a professional teaching model [1], the construction principles are:

\subsubsection{The principle of career orientation}

Based on the background of accounting internationalization, the demand for talents in society is constantly increasing, and there is a high standard for the overall quality and professional competence of accounting personnel. Nowadays, the employment pressure faced by students of accounting major in China is very large. The establishment of a professional teaching model for the cultivation of accounting capacity in colleges and universities must be based on the premise of cultivating students' employability and entrepreneurial ability, facing society, markets and students, and meeting the standards of accounting profession.

\subsubsection{The principle of practicality}

The standard of accounting education for students can not only be in terms of accounting knowledge, but also allow students to have strong analytical skills. The cultivable professional teaching model must be operability and practical, and must be linked with accounting practice to cultivate High-quality accounting personnel.

\subsubsection{The principle of innovation}

In order to meet the development tendency of the modern economy, accounting methods and services are continuously improved and adjusted. The accounting teaching model is also gradually innovating and optimizing in accordance with the requirements of the society's standards, and applying the innovative education science to teaching effectively.

\subsubsection{The principle of adaptability}

A good teaching model must comply with the economic development situation and the demand of the enterprise for accounting personnel, and fully mobilize the students' enthusiasm for learning and initiative.

\subsubsection{The principle of integration}

The cultivation of competence is the core of the teaching model. At the same time, it is also necessary to constantly learn and accumulate new knowledge so as to develop good humanistic qualities and professionalism. 


\section{The Construction Ideas of Ability Training Teaching Mode}

Based on the background of accounting internationalization, while determining the occupational structure of accounting personnel, we must also adopt a new type of accounting education philosophy, a scientific teaching model and teaching method to build a teaching pattern based on training ability.

\subsection{Learn from foreign teaching experience.}

Compared with the international accounting industry [4], China's accounting industry still has some distances. It is mainly displayed in the executive ability and level of accounting personnel, and some of the more advanced cities and regions in the world are worth learning and reference for all universities in the model of accounting personnel training. The United Kingdom is the birthplace of the accounting profession, and it has always attached great importance to the education of accounting and is based on the principle of "focusing on the cultivation of students' qualities and abilities". Australia's capacity-building teaching model has the ability to independently learn, analyze and judge, and deal with problems. Canada's major capacity-building education model is based on the CBE model. In this regard, our country must build a teaching model with training ability as the core under the background of accounting internationalization, and change the traditional educational thought. [2]

\subsection{Build accounting teaching models in line with international practices.}

With the accelerating pace of accounting internationalization, China will have to train more qualified international accounting personnel and adapt it to the internationalization of accounting education. This requires that colleges and universities develop professional accounting skills to build a set of accounting teaching models in line with international practice, and set up international courses. With the main purpose of cultivating ability, accounting courses can be based on the scope of other disciplines to create a "thick foundation, wide caliber, high standard" curriculum system, mainly includes four aspects: professional compulsory courses, public compulsory courses, professional basic courses and professional elective courses. Using hierarchical, systematic, modular and integrated curriculum models to improve the curriculum framework, innovate teaching content, and add teaching scenarios to allow students to form a basic thinking model and knowledge structure, making the curriculum system in the framework and the students' comprehensive ability coordination. Conformity with professional posts in the teaching mode can adapt to the development of accounting internationalization. Thick foundation refers to students improving their literacy through public essential lessons; wide caliber refers to students developing their professional abilities through professional basic courses and professional compulsory courses; high standards refer to students passing through professional elective courses. Lay a solid foundation for future senior work.

\subsection{Innovative teaching methods and teaching means.}

Through innovative teaching methods and teaching means, students can display their skills and conform to the students' cognitive rules, which can help students obtain more information. Relevant scholars have innovated teaching methods, and facts prove that innovative teaching methods can enhance students' understanding of knowledge, strengthen teamwork awareness and improve interpersonal skills. The main purpose of the accounting education is to use more teaching methods and teaching means to stimulate students' ability and purpose of self-learning from the root and further deepen their understanding of professional knowledge so as to cultivate students' comprehensive ability. Using case teaching methods to improve students' ability to observe problems, analyze problems and solve problems; using interactive classroom teaching to guide students to actively participate in school activities, strengthen interpersonal communication and language expression skills; using grouped learning to improve students' needs in accounting work. The interpersonal relationship and cooperation methods provide convenience for solving difficult problems; establish special lectures and give detailed explanations on the key points of accounting, 
auditing, finance, then students' interests in learning and understand the national accounting policies, laws and regulations of economics are fully inspired. As well as the industry situation, improving the students' theoretical skills; using the practice teaching method to reproduce the situation of the job environment, selecting the business information of the appropriate industry or company, cultivating students' operational ability and professional judgment ability; training students' ability to write thesis and collect information. In the teaching process, the teacher applies modern teaching methods to improve the teaching efficiency of the school. In addition, the network technology can also be used in teaching, combining text, video, images and other information together to set the situation, inspire students' imagination, so as to cultivate students' innovative ability. [7]

\subsection{Build a sound assessment system.}

The traditional professional teaching evaluation system attaches too much importance to the theoretical knowledge and results, thus ignoring the students' professional skills and learning process. The students' performance is the main body, and the evaluation method is relatively single, which limits the students' creativity and makes it difficult to improve the students' comprehensiveness, ability and professionalism. With the accelerating trend of accounting internationalization, it is required that the accounting profession in various universities must meet the development needs of the market, diversify the main body of evaluation, and diversify the evaluation methods into the assessment system. In addition, students should be self-evaluated and evaluated by teachers. Their peer evaluation and expert evaluation are also included in the assessment system. They are based on competency assessment. Students' theoretical knowledge and basic knowledge are used as assessment criteria. At the same time, their professional ethics, work attitude, and life values are evaluated. Whichever method is selected for evaluation, we must put the principle of fairness and justice in the first place and build a sound assessment and evaluation system. [5]

\section{Conclusion}

To sum up, with the rapid development of China's modern economy, accounting has gradually developed toward the international direction, China's accounting regulations and accounting practices have been pushed to a higher level and are in line with international standards. In order to meet the society's demand for accounting talents and the current development trend, only by constructing the accounting professional teaching model and teaching evaluation system can we fundamentally cultivate students' professional skills, so as to improve students' comprehensive quality and practical ability.

\section{References}

[1] Zhang Hailan, Xing Weiping. Discussion on the Construction of Accounting Specialty Teaching Model in Colleges and Universities_-Based on the Thinking of Ability Cultivation in the Background of Accounting Internationalization[J]. Finance and Accounting Communications, 2013, (28): 40-41.

[2] Gu Meijun. The construction of Internationalized Accounting Personnel Training Teaching Evaluation and Model Reform [J]. Modern Marketing Journal, 2015, (6): 80-81.

[3] Zhu Jing. Current Status and Countermeasures of Accounting Education and Accounting Education Research [J]. Modern Economic Information, 2014, (10): 447-448.

[4] He Hong. Comparison of Chinese and Foreign Talents in International Accounting Training[J]. Education and Occupation, 2011, (14):

[5] Jing Shuo. Thinking and Suggestions on Practice Teaching of Accounting Majors in Colleges and Universities [J]. Education Teaching Research, 2015, (16):52-54.

[6] Yang Liang, Zhang Qi, Bai Lijun. The cultivation of Accounting Professional and Technical 
Talents in the Context of University Restructuring [J]. Education and Occupation, 2016, (6) pp 4850 .

[7] Tang Hengshu. Discussion on the Characteristics of Running School under the Background of University Transformation [J]. Science Guide, 2014, (10): 102-103.

[8] Liu Yuxi. Research on Accounting Talent Cultivation of Applied Undergraduate Colleges in the Background of Accounting Education Internationalization[J]. Chinese and foreign entrepreneurs, 2016, (29): 